\title{
Sillence syndrome
}

INSERM

\section{Source}

INSERM. (1999). Orphanet: an online rare disease and orphan drug data base. Sillence syndrome. ORPHA:3168

Sillence syndrome (brachydactyly-symphalang ism syndrome) resembles type A1 brachydactyly (variable shortening of the middle phalanges of all digits) with associated symphalangism (producing a distal phalanx with the shape of a chess pawn). Scoliosis, clubfoot and tall stature are also characteristic. 